\title{
Impact of Covid-19 to Halal Tourism in Turbulence Economy on $\mathbf{H}$ Theory
}

\author{
Roikhan Mochamad Aziz \\ \{hahslm.study@gmail.com\} \\ Universitas Islam Negeri Syarif Hidayatullah Jakarta, Indonesia
}

\begin{abstract}
This study aims to discourse between the sharia sector and the economic sector in the pandemic Covid-19 phenomena with Islamic religion rooted in Allah that can be merged in it by one faith in Islam as salat. Salat is the first design before human had been created. Methodology in this research was carried out using a qualitative descriptive approach that collects data on field notes, personal documentation, and other official records which will be used as proof provided. Hahslm theory is reflected in tourism as guidance to tourism from God with the reflexivity of worship. Islam is derived from $\mathrm{s}, 1, \mathrm{~m}$ for the entire structure that Islam will understand on earth is required. It requires a kaffah system to cover three principal things: God, nature, and worship. The research can conclude that sharia tourism is tourism that combines the concepts of conventional tourism and religious tourism by always paying attention to halal and haram benchmarks in its implementation.
\end{abstract}

Keywords: Hahslm, Shalat, Tourism, Economics, Covid-19

\section{Introduction}

Currently, the tourism industry has made a major contribution to increasing economic growth in Indonesia. Based on information obtained from the official website of the Republic of Indonesia's Ministry of Tourism, contributions gained by Indonesia from the tourism sector are earned from foreign exchange earnings, national profits, national growth, as well as through the absorption of investment and labor and market creation distributed through various parts of Indonesia. Indonesia is the biggest muslim country in the world. And the muslim have obligation to do worship as Quran 51.56 where salat is the root of worship as the initial blueprint of creation [1]. According to the Ministry of Tourism's Pocket Book, the tourism industry led to increasing the national Gross Domestic Product (GDP) to 9 percent or around Rp 946.09 trillion in 2014. In Indonesia, the tourism industry also plays a part in job development. This can be seen from data on donations to job openings that exceeded 11 million people in 2014 [2]. Consistent with this increase, the Regional Medium-Term Development Plan 2015-2019 has made tourism sector growth an element in supporting national economic growth.

Islamic tourism essentially has a definition that combines aspects of tourism with Islamic values. The Islamic values aspects can be attached to the accommodation elements, restaurants, to the whole set of activities that refer to Islamic norms. The philosophy of Sharia tourism is the actualization of the philosophy of Islam in which the main criteria are halal and haram standards, which ensures that all facets of tourism operations are inseparable from halal certification, which must be a reference point for any tourism participant. The concept of Sharia tourism can also be interpreted as worship and da'wah-based tourism activity, while Muslim tourists can travel and 
admire the results of the creation of Allah SWT (nature tafakur) by continuing to fulfill compulsory prayer obligations five times a day and all this is well facilitated and removed from all that He prohibits.

The planet is now stunned by the occurrence of the spread of a plague caused by the coronavirus. The coronavirus was first discovered in Wuhan city, China. This viral infection is known as Covid-19. This virus has a relatively high rate of dissemination. Coronavirus or Coronavirus 2 (SARS-CoV-2) Extreme Acute Respiratory Syndrome is a virus that affects the respiratory system and can cause serious to minor respiratory infections that can cause death in patients. The widespread propagation of the virus across the world worldwide harms the global economy. The tourism business is one of the impacts of the Covid-19 pandemic. The coronavirus that spread very quickly from humans to other individuals allows this disease to affect many countries around the world. As a result, many countries around the world are introducing a lockdown strategy to minimize the rapid transmission rate, a strategy that limits entry to and exit from goods or individuals overseas and inside the country for some reason. The presence of these policies impacts the domestic tourism industry, as the tourism sector includes human beings as the key asset in its operation. Therefore, due to the spread of the coronavirus, airlines, hotels, restaurants, and travel agencies who rely on their revenue from visitors are experiencing a crisis. The effect of the tourism sector will affect domestic economic development where the tourism sector is one of the foundations of the Indonesian economy in Indonesia itself.

\section{Research Methods}

\subsection{Research Scope}

To order to explain the topic that needs to be addressed so that the conversation isn't too broad or deviating, a question boundary is required. The scope of the topics that will be addressed in this journal's writing is mainly in the framework of the Covid-19 epidemic related to sharia tourism, fasting, the Hahslm hypothesis, the environment, and the current world conditions. The subject to be explored in this article is how the relationship between the factors to which the economy has been referred. In this article the area to be addressed is:

a. This study will concentrate on the consequences and connections between variables of Covid-19, sharia tourism, meditation, Hahslm theory, and the economy.

b. The research study is qualitative, that is, the evidence collected by analyzing many essential documents and reports which are then comprehensively analyzed and presented in word form.

c. This methodology is considered appropriate because this research wants to know the qualitative variables and not the quantitative of the variables, so these results are valid.

\subsection{Data Determination Method}

There are several variables in this analysis, including Islamic tourism, prayer, Hahslm theory, economy, and Covid-19. To identify each variable and help the research phase in this report, we need some data used, such as positive coronavirus data, data on patient recovery, coronavirus death data as a predictor of Covid-19 transmission in Indonesia. Also, foreign exchange income, GDP, and sharia tourism growth data are used as Indonesian economy 
indicators. Moreover, to assess their association with Covid-19 and the Indonesian economy, many hypotheses and study evidence on prayer and Hahslm theory is used.

The authors use supplementary data gathered indirectly in this analysis as the authors collected data from official websites and publications such as newspapers or other official writings in this analysis.

For this analysis, the authors mixed qualitative and quantitative data with specific statistical criteria due to the existence of the variables. Quantitative data is data in the form of numbers (numeric) and qualitative opposite, i.e. data in the form of numbers and is not. Ghony and Almanshur [3], qualitative analysis technique, is a study that produces new results that are collected with careful observation during the data collection process and involves a detailed overview followed by notes of certain documents that are then analyzed in full and thorough form.

\subsection{Data Collection Method}

The process for collecting samples is performed using Observation and Record Analysis. Observation is a dynamic method of data gathering since it includes a variety of variables in its execution. This approach can also be used to document different events that exist such as the pandemic Covid-19 in the process of gathering observation data is not just a matter of the respondents' attitude.

The investigator's data collection is non-participant evaluation since the scientist is not actively interested in the events or procedures found in the analysis process. This method of data collection is considered appropriate as this practice is used to study human behavior, work processes, and natural phenomena.

This is the method of document analysis, the method of document research is to collect evidence or information by reading documents, reports, summaries, written comments, and other writings [4].

\subsection{Data Analysis Method}

This study uses a descriptive method of qualitative data analysis, a method that gathers information and data through literature study, literature exploration, and several documents and other official records that are then fully and comprehensively reviewed. The writers in this study identify the notion of Islamic economics, Islamic prayer, Hahslm theory, and Covid-19. Then continue with a critical and thorough study of how these factors in human lives and the economic environment can be linked and influence one another.

Descriptive qualitative research method according to Emzir [5] is a research method which refers to sentences or words rather than numbers, such as field notes, personal documents, and other official records with the findings in the form of quotes from the data obtained, and the data will later be used as proof presented. Meanwhile, according to Hanafi [6] in his book entitled "Language Study Methods for Analysis, Thesis and Dissertation" qualitative research is analysis whose question focuses on the explanation of the observed symptoms and aims to locate a truth or facts based on subjects examined with a natural approach, such as observing, questioning, reading, and writing.

Work that explores the ramifications and relationships between sharia tourism, prayer in Islam, Hahslm economic theory, and Covid-19 is very appropriate by using concise qualitative approaches, based on expert opinions on concise standard measures. Since while the research in this analysis is collaborative, which is to combine quantitative data and qualitative data, there 
are no data gathered by the author by mathematical testing, such that the presentation is in the form of terms and explanations only.

\subsection{Research Limitation}

For the time and location from March to April 2020, attributable to government policies that advise not undertaking things outside the home to enforce social distancing. Therefore, to avoid the dissemination of Covid-19, the method of face-to-face learning practices was converted into online instruction. That's in line with Chancellor Circular No. HK.00.7/3/2020 B.885/R. The data obtained on Covid-19 is gathered based on data submitted between January and April 2020. Certain evidence, though, that was gathered successfully in a review of data that occurred a long time ago.

\section{Results and Discussion}

The growth of an increasingly exponential age makes life harder in terms of tourism for all human activities. Tourism experiences are pretty convenient for all in the modern technology age as there are so many inexpensive tourism destinations with easy access that people of all classes can enter. Tourism practices have now become part of the community's desire to achieve personal self-satisfaction. Nevertheless, if the joy satisfied the divine dimensions or is restricted only to the fulfillment of the pleasure of the world and whether the tourist practices are promised advantages in achieving the blessing of Allah SWT. Starting from these issues, the tourism industry was created that could satisfy human needs in terms of a person's fulfillment as well as moral happiness, the new industry was called sharia tourism.

The Quran does not mention directly about tourism. There are several analyses related to tourism. Sara or command, endeavor (effort), and the desire to travel as in the letter Jonah: 22 (Al-Ashafaniy, 2002). A total of 27 verses that include the words sara 14 of them encourage humans to travel which are all accompanied by the command mentadabbur or pay attention. In the Qur'an and Sunnah, it is explained several purposes in making a journey.

From the Islamic perspective, Islamic tourism activities are directed by the principles of ta'arruf (mutual acquaintance), tabadul al-manafi (exchange of benefits) and ta'awwun, and takaful (helping each other and bearing risks). Therefore, one of the missions of tourism science in Islam is to formulate scientifically and systematically efforts to maximize the benefits of tourism and minimize its negative impacts [7].

Indonesia is known as the biggest Muslim country in the world. And Muslims must worship Allah. And worship can be tapped as reflexivity in life as QS Ad Cultural property owned by Indonesia is illustrated by the many ethnicities, races, and religions, each of which has a different culture and culture. Not only that, but Indonesia is also rich in history that accompanies this country, which is still standing today. Indo-Dzariyat [51]: 56. Indonesia is known to the world as a multicultural country rich in civilization. It was then encouraged the interest of the international community and local communities to make tourism trips to Indonesia which have increased. This is proven through data quoted from the official website of the Central Statistics Agency each year. Indonesia has an increase in local and international tourists seen from 2015 where the number of foreign tourists visiting Indonesia amounted to 10 million to 15 million in 2018. This indicates an increase in demand in the sector of Indonesian tourism. 
As explained in the previous section about increasing demand for the tourism sector by the Indonesian people, so too is the demand for sharia tourism in Indonesia which also indirectly contributes to the growth of the national economy. This is directly proportional to the increasing number of Indonesian Muslims who make Islam the majority religion in Indonesia.

Based on research conducted by the United Nations World Tourism Organization in 2016, Indonesia is in the position of the Top 5 World Halal Tourism Destinations with total foreign exchange revenues reaching the US\$13 billion and affecting the Gross Domestic Product (GDP) of US\$ 57.9 billion. So in 2020, sharia tourism is projected to continue to be the largest contributor to the country's foreign exchange earnings in the context of increasing Indonesia's economic growth. Therefore, in achieving these goals the Ministry of Tourism and Creative Economy has now determined that there are at least nine regions in Indonesia that have the potential to be used as sharia tourism destination development, including West Sumatra, Riau, Lampung, Banten, Jakarta, West Java, East Java, Makassar, and Lombok. Certainly, the stipulation of these areas is a step of the government in developing the tourism potential contained in each of these areas so that it can also be converted into an Islamic tourism area and its output is expected to attract more tourists who come so that it can also increase GDP through economic equality in Indonesia. So based on the previous explanation above, it can be concluded that the sharia tourism sector and the economy in Indonesia have a connection because, with the presence of a new tourism style, it can attract more visitors and will increase state revenue through certain regions that empower tourism potential in the area. With the increase in state revenue, it is expected to improve or even improve the economic stability of the Indonesian state.

Next is how to link the elements of sharia tourism with the Hahslm analysis. The analysis Hahslm according to Roikhan [8] is a complete set/whole system/integrated part consisting of three main elements, namely primary (creator/intermediary), secondary (creation/receiver), tertiary (worship/transmitter) that can be positively or negatively charged, so that of the three elements will be composed a statement where the secondary will be below the primary will do tertiary (humans were created by God to worship). It also relates to the contents of the Qur'an which reads kaffah silmi which is formed through the letters sin lam mim, where there is a symbiosis between God, nature, and worship. If symbiosis is a comprehensive kaffah system, then it can be ascertained that the symbiosis consists of the variables of God, nature, and worship.

From the above explanation, it can be seen that even in sharia tourism there is an element of connection between God (Allah SWT), nature (tourist destinations), and worship (a series of activities and use of sharia tourism facilities).

The last few months of the world were rocked by the Covid-19 outbreak that attacked almost all corners of the world. The virus suspected to originate from China has made many influences on the lives of the world community. In the end, made this outbreak as a pandemic and a world emergency because of its rapid spread.

Severe acute respiratory syndrome coronavirus 2 (SARS-CoV-2), initially named novel coronavirus or 2019-nCoV, is a single-stranded RNA virus that forms one of the seven coronaviridae [9]. On 30th January 2020, the WHO declared the Chinese outbreak of Covid-19 to be a Public Health Emergency of International Concern posing a high risk to countries with vulnerable health systems. The emergency committee has stated that the spread of Covid-19 may be interrupted by early detection, isolation, prompt treatment, and the implementation of a robust system to trace contact [10].

World phenomena related to epidemics caused by Covid-19 can be external shocks that affect the financial system and the economy in Indonesia. As is known, that the economy has a 
fluctuating nature means that an economy can not be predicted to increase and decrease. It depends on factors that can affect the economy itself. One factor that can affect the economy is global phenomena such as the Covid-19 outbreak. Covid-19 can affect the stability of the financial system and the Indonesian economy because the Indonesian economy with the world is connected or in other words countries in the world work together and interact to help each other in the economy.

Covid-19 outbreaks appear and spread with very rapid transmission rates. This affects economic activities between countries and even the world. In Indonesia alone, the increase in the total number of cases continues to increase over time. According to data from the Ministry of Health of the Republic of Indonesia there are about 10,000 more than the total number of total cases. Concerns between Indonesia and countries in the world of Covid-19 that spread very quickly resulted in several countries imposing a lockdown policy, a policy that limits all activities in and out of an area on the grounds to prevent the spread of Covid-19 outbreaks to spread. This results in economic activity records that become disrupted, one of them is world trade activities (exports and imports). China is the main trading partner of Indonesia and the country of origin for Indonesia's largest imports and non-oil and gas export destinations. Total exports to China in 2019 reached USD 25.85 billion, while imports reached USD 44.58 billion (katadata.co.id). Based on data released by BPS [11], non-oil and gas exports in January 2020 decreased compared to December 2019. This decline occurred in part one of the main destination countries, one of which is China, which reached USD 211.9 million, down 9.15\%. While the value of non-oil and gas imports in January 2020 also declined. The total value of non-oil and gas imports during January 2020 was USD 9,670 million or decreased by USD 313.5 million or down $3.14 \%$ compared to December 2019. This was caused by the decline in the value of non-oil and gas imports from several major countries, one of which was China from USD 4.07 billion to USD 3.94 billion or down 3.08\%. The disruption of export and import activities will have an impact on industrial activity and the domestic economy where industrial raw materials and the needs of some sectors in Indonesia are still dependent on imports from other countries. This will increase in the overall price of goods, even more so followed by surging demand due to public panic over the condition. In addition to the disrupted trading system, this outbreak also affected the Composite Stock Price Index (ISHG) which had dropped 6.24 percent on March 9, 2020 and the rupiah exchange rate had weakened to Rp. 16,000 to the US Dollar.

Therefore, the explanation above shows that the Covid-19 outbreak had a very significant impact on the economy and the tourism sector in both conventional and sharia forms.

The influence that was created by the Covid-19 outbreak was not only on economic-related fields, but other community activities such as religious worship, one of which was the worship of Muslims was also affected by the Covid-19 outbreak. to stay home and not make large gatherings in the region. As a result of this policy, all activities in places of worship such as mosques were abolished such as the five daily prayers in congregation, Friday prayers, scientific studies, and so forth. This is by the MUI fatwa No. 14 of 2020 concerning organizing worship in situations of the outbreak of Covid-19 as a form of avoiding this epidemic to become more widespread.

In the teachings of Islam also explained about avoiding epidemics, the Prophet Muhammad once said firra minal majdzûmi firaraka minal asad. "You should flee" - meaning avoid - "from a person affected by leprosy, just as you have to run from a lion". Close to people who have leprosy, the same as people who are close to lions. That is when there is an outbreak of disease we must always be trustworthy and vigilant not to let the disease be contagious. This is in line with the PSBB policy and the ban on congregational prayers at the mosque in the congregation. 


\section{Conclusion}

From the explanation above, it was concluded that sharia tourism is tourism that combines the concepts of conventional tourism and religious tourism by always paying attention to halal and haram benchmarks in its implementation. Sharia tourism also contributes greatly to the Indonesian economy. Sharia tourism is good in addition to providing the beauty of tourist destinations that can strengthen the values of Islam. The sharia tourism sector also does not forget aspects of Islamic values derived from Allah through the Qur'an and Sunnah in providing limits on the scope of sharia tourism. Sharia tourism is one of the new leading sectors. The government has made a push in the form of incentives for the tourism sector so that its survival is maintained. These steps are considered to have no significant effect due to conditions that do not allow tourists to travel. Not only the tourism sector was disrupted but the entire economic sector was also disrupted due to this outbreak.

Spiritual needs must always be maintained because at this stage many people feel hopeless. Therefore the role of prayer is very important for Muslims. With prayer, people feel close to Allah and can reduce depression experienced by someone.

\section{References}

[1] R. M. Aziz, Islam dan Pengetahuan. Jakarta: Salemba Diniyah, 2018.

[2] R. W. Anggraini, "Analisis Pengaruh GDP, Inflasi, SBIS dan Kurs terhadap Resiko Pembiayaan Perbankan Syariah Periode 2012-2017," 2017.

[3] M. D. Ghony and F. Almanshur, "Metodologi penelitian kualitatif," Jogjakarta: Ar-Ruzz, Media, vol. 61, 2012.

[4] N. Nilamsari, "Memahami studi dokumen dalam penelitian kualitatif," WACANA J. Ilm. Ilmu Komun., vol. 13, no. 2, pp. 177-181, 2014.

[5] Emzir, Metodologi Penelitian Kualitatif: Analisis Data. Jakarta: Raja Grafindo Persada, 2010.

[6] A. H. Hanafi, Metode Penelitian Bahasa Untuk Penelitian, Tesis, dan Disertasi. Jakarta: Diadit Media, 2012.

[7] M. Muhajirin, "Pariwisata Dalam Tinjauan Ekonomi Syariah," Al-Mashlahah J. Huk. Islam dan Pranata Sos., vol. 6, no. 01, pp. 91-103, 2018.

[8] R. M. Aziz, "Teori H Sebagai Ilmu Wahyu Dan Turats Dalam Islam,” J. Ushuluddin, vol. 24, no. 1 , pp. 103-112, 2016.

[9] M. Nicola, N. O’Neill, C. Sohrabi, M. Khan, M. Agha, and R. Agha, "Evidence based management guideline for the COVID-19 pandemic-Review article," Int. J. Surg., 2020.

[10] C. Sohrabi et al., "World Health Organization declares global emergency: A review of the 2019 novel coronavirus (COVID-19)," Int. J. Surg., vol. 76, pp. 71-76, 2020.

[11] "Wisatawan Mancanegara yang datang ke indonesia menurut kebangsaan 2015-2019," Badan Pusat Statistik, 2020. [Online]. Available: https://www.bps.go.id/dynamictable/2020/04/07/1794/wisatawan-mancanegara-yang-datang-keindonesia-menurut-kebangsaan-2015-2019.html. 